\title{
APLIKASI MIKORIZA DAN AZOLLA TERHADAP KEBUTUHAN AIR DAN HASIL BAWANG MERAH PADA LAHAN MARJINAL
}

\section{Application of Mycorrhiza and Azolla on Water Requirement and Yield of Shallot in Marjinal Land}

\author{
Begananda*, Eny Rokhminarsi dan Darini Sri Utami \\ Fakultas Pertanian, Universitas Jenderal Soedirman Purwokerto \\ Jl. dr. Soeparno, Purwokerto
}

*Alamat Korespondensi: bega_nanda@yahoo.co.id

\begin{abstract}
ABSTRAK
Penelitian ini bertujuan mengkaji pengaruh pupuk hayati mikoriza+azolla dengan pengurangan dosis anjuran pupuk $\mathrm{N}, \mathrm{P}$, dan $\mathrm{K}$ terhadap kebutuhan air, titik layu permanen, porositas, berat jenis isi, berat jenis partikel, dan hasil tanaman bawang merah pada tanah ultisol. Rancangan percobaan yang digunakan adalah RAK faktorial dan diulang tiga kali. Faktor yang dicoba adalah dosis pupuk hayati mikoriza + azolla dengan tiga taraf, yaitu $10 \mathrm{~g}$ pupuk mikoriza $+0 \mathrm{~g}$ pupuk azolla, $20 \mathrm{~g}$ pupuk mikoriza $+10 \mathrm{~g}$ pupuk azolla, dan $30 \mathrm{~g}$ pupuk mikoriza +20 g pupuk azolla per tanaman, dan pengurangan dosis anjuran pupuk N, P, dan K yang terdiri atas $0 \%, 25 \%$, dan $50 \%$. Variabel yang diamati antara lain air tersedia, berat jenis isi, berat jenis partikel, porositas, batas cair, batas berubah warna, tinggi tanaman, bobot umbi segar, bobot umbi kering per polibag. Hasil penelitian menunjukkan bahwa aplikasi pupuk hayati mikoriza+azolla dapat menurunkan kebutuhan air tanaman, bobot umbi kering dan berat jenis isi tetapi tidak berpengaruh pada berat jenis partikel, porositas, titik layu permanen, tinggi tanaman, dan bobot umbi segar. Aplikasi pupuk hayati mikoriza+azolla $30 \mathrm{~g}$ per tanaman mampu mengurangi dosis pupuk N, $\mathrm{P}$, dan K sekitar $43 \%$.
\end{abstract}

Kata Kunci : Bawang merah, kebutuhan air, Mikoriza, Azolla

\begin{abstract}
The objective of this study was to know the effect of mycorrhizal + Azolla biofertilizers by reducing the recommended dosage of $N, P$, and $K$ fertilizers on water requirement, permanent wilting point, porosity, bulk density, particle density, and shallot yields on ultisol soil. The experimental design used was Randomized Complete Block Design (RCBD) and repeated three times. The factors of dosage of mycorrhizal + azolla biofertilizers i.e. $10 \mathrm{~g}$ of mycorrhizal fertilizer $+0 \mathrm{~g}$ of azolla fertilizer, $20 \mathrm{~g}$ of mycorrhizal fertilizer $+10 \mathrm{~g}$ of azolla fertilizer and $30 \mathrm{~g}$ of mycorrhizal fertilizer $+20 \mathrm{~g}$ of Azolla fertilizer per plant, and reduction in recommended dosages of fertilizer N, P, and K consisting of 0\%, 25\%, and 50\% were tested. Variables observed were available water, bulk density, particle density, porosity, liquid limit, color change limit, plant height, fresh tuber weight, dry tuber weight per polybag. The results showed that the application of mycorrhizal + azolla biofertilizers could reduce plant water requirements, dry tuber weight and bulk density but did not significantly effect on particle density, porosity, permanent wilting point, and plant height, and weight of fresh tuber. Application of mycorrhizal + azolla biofertilizer $30 \mathrm{~g}$ per plant could reduce dosage of $N, P$, and K fertilizers about 43 percent.
\end{abstract}

Keywords: Shallots, water requirements, mycorrhiza, Azolla

\section{PENDAHULUAN}

Bawang merah merupakan salah satu komoditi sayuran unggulan yang sejak lama telah dibudidayakan oleh petani secara intensif. Hal tersebut karena bawang merah merupakan sumber pendapatan dan kesempatan kerja yang memberikan kontribusi cukup tinggi terhadap perkembangan ekonomi wilayah (Badan Litbang Pertanian, 2007). Salah satu kendala dalam peningkatan produksi bawang merah adalah terbatasnya lahan subur untuk penanaman, sehingga perlu diarahkan pada tanah yang kesuburannya 
rendah seperti tanah ultisol. Di Indonesia luas lahan kering marjinal yang umumnya didominasi oleh ordo ultisol mempunyai potensi jauh lebih besar dibandingkan dengan lahan sawah dan atau lahan gambut. Luasnya mencapai sekitar 48,3 juta hektar atau $\pm 25,4 \%$ dari luas daratan Indonesia. Hambatan yang sering dijumpai adalah rendahnya tingkat produktivitasnya. Apabila kesuburannya dapat ditingkatkan, maka sangat berpotensi dalam mengendalikan stabilitas produksi pertanian (Yuwono, 2009). Secara umum permasalahan yang dijumpai baik pada sifat fisik, kimia, dan biologis tanah antara lain retensi air yang rendah dan peka terhadap erosi, kemasaman yang tinggi $(\mathrm{pH}<5)$, kandungan hara $\mathrm{N}, \mathrm{P}, \mathrm{K}, \mathrm{Ca}, \mathrm{Mg}, \mathrm{S}$ rendah, KTK rendah lebih kecil dari 24 me $100 \mathrm{~g}^{-1}$, $\mathrm{KB}$ rendah (biasanya <35\%), kandungan $\mathrm{Al}, \mathrm{Fe}$, dan Mn tinggi, kandungan bahan organiknya, dan aktivitas kehidupan biologinya rendah. Kendala lain yang dihadapi adalah kahat unsur hara mikro Zn, $\mathrm{Cu}$, B dan Mo (Hardjowigeno, 2007). Tanah Ultisol juga mempunyai beberapa permasalahan seperti aerasi yang buruk, stabilitas agregat rendah, laju infiltrasi, permeabilitas lambat dan daya pegang air rendah (Syarief, 1985).

Pemanfaatan mikoriza dan azolla merupakan inovasi teknologi yang dapat dikembangkan guna memperoleh sistem pertanian berkelanjutan dengan hasil yang tinggi (Setiadi, 1998). Menurut Sasli (2004), pemanfaatan mikoriza dan azolla dapat diterapkan untuk menurunkan kebutuhan air tanaman. Hal tersebut karena hifa cendawan mikoriza masih mampu untuk menyerap air dari pori-pori tanah saat akar tanaman kesulitan menyerap air (Setiadi, 1998). Menurut Masria (2008), kemampuan menyerap air dari pori-pori tanah karena hifa mikoriza membentuk percabangan yang lebih kecil dan lebih halus dari rambut akar dengan diameter kurang dari $1 \mu \mathrm{m}$, sehingga dapat menyusup kedalam pori-pori tanah yang paling kecil (mikro). Pemanfaatan cendawan mikoriza sebagai pupuk hayati juga dapat meningkatkan ketersedian dan serapan hara fosfat dan hasil tanaman bawang merah (Ansyar et al., 2017), dan penggunaan bersama dengan azolla dapat mengurangi pupuk anorganik sebesar $43 \%$ dari anjuran (Rokhminarsi et al., 2007). Menurut Fuady (2013), mikoriza juga merupakan salah satu cendawan yang dapat memantapkan struktur tanah. Faktor lain dalam budidaya bawang merah adalah pemakaian input produksi yang tinggi sehingga dapat mengurangi pendapatan petani. Faktor produksi yang banyak dipakai dalam budidaya tanaman bawang merah adalah pupuk dan pestisida sintetis yang dapat mengakibatkan pencemaran lingkungan dan produk yang dihasilkan, sering 
menghilang di pasaran, bahkan dipalsukan sehingga hasilnya tidak optimal.

Di lain pihak, efisiensi pupuk yang terserap tanaman di daerah tropis relatif rendah, yaitu pupuk urea hanya sekitar 20$30 \%$, pupuk $\mathrm{KCl}$ sekitar $30-50 \%$ dan efisiensi SP-36 lebih rendah dibandingkan Urea dan KCl (Simarwata et al., 2001). Oleh karena itu, strategi peningkatan produksi tanaman bawang merah ditekankan pada percepatan pertumbuhan produksi berbasis peningkatan inovasi teknologi yang ramah lingkungan dan berkelanjutan (Adiyogo, 1999), serta berbasis sumberdaya dan kearifan lokal, yaitu dengan pemanfaatan pupuk mikoriza spesifik lokasi berbasis azolla pada lahanlahan tidak subur seperti Ultisol. Jamur mikoriza yang sering digunakan dalam dunia pertanian adalah mikoriza arbuskula. Jamur Mikoriza Arbuskula (MA), merupakan jamur yang bersifat obligat simbiosis, dan harus tumbuh pada suatu tanaman inang yang masih hidup (Habte and Manjunath, 1991).

Inovasi paket bioteknologi yang mendukung hal tersebut dan perlu dikembangkan, yaitu dengan pemanfaatan pupuk alternatif mikoriza spesifik lokasi berbasis azolla (Mikola). Jamur mikoriza merupakan jamur tanah yang mempunyai peran dalam membantu menyediakan nutrisi bagi tanaman, sehingga mampu mengurangi pemakaian pupuk sintetis dalam budidaya pertanian. Hal ini sangat dibutuhkan terutama pertanian lahan kering marjinal yang mempunyai tingkat produktivitas tanah rendah.

Bioteknologi pupuk hayati mikoriza berbasis azolla (Mikola) sebagai pupuk alternatif pada tanaman sayuran merupakan inovasi baru, karena apabila terjadi sinergi dapat bersifat multifungsi dalam mewujudkan pertanian berkelanjutan untuk mendukung ketahanan pangan, yaitu mampu menyediakan nutrisi dan air bagi tanaman, menekan patogen tular tanah, meningkatkan ketahanan tanaman terhadap hama dan penyakit yang pada akhirnya menghasilkan sayuran yang aman dikonsumsi (organik), serta lingkungan tetap terjaga. Selama ini pemanfaatan mikoriza atau azolla masih dilakukan secara terpisah, sehingga tidak dapat bersifat multifungsi dalam mengatasi permasalahan kesuburan tanah, lingkungan, produksi, serta hama dan penyakit tanaman secara bersamaan. Berdasarkan pemikiran tersebut, perlu dikaji lebih lanjut aplikasi pupuk Mikola yang merupakan mikroba spesifik lokasi untuk pengembangan tanaman sayuran melalui bioteknologi yang berbasis sumberdaya dan kearifan lokal lahan marjinal.

Tujuan penelitian adalah: 1) meningkatkan produktivitas dan mengembangkan tanaman sayuran sehat, sehingga ikut mendukung ketahanan 
pangan di dalam negeri, 2) meningkatkan produktivitas lahan marjinal, 3) ikut mewujudkan pertanian berkelanjutan dengan menekan pencemaran lingkungan yang disebabkan oleh pemakaian pupuk dan pestisida sintetis, 4) mengurangi ketergantungan petani terhadap pupuk dan pestisida sintetis yang selama ini menjadi masalah bagi petani akibat harganya terus melambung, sering menghilang dari pasaran pada saat dibutuhkan petani atau bahkan sering dipalsukan. Hipotesis yang diajukan adalah pemanfaatan pupuk hayati mikoriza spesifik lokasi lahan marjinal berbasis azolla (Mikola) dapat mengurangi penggunaan pupuk anorganik (Urea, SP 36 dan $\mathrm{KCl}$ ), serta meningkatkan hasil bawang merah.

\section{BAHAN DAN METODE}

Percobaan dilaksanakan pada bulan Maret sampai Oktober 2018 dilahan petani desa Kaliori, kecamatan Kalibagor, kabupaten Banyumas, laboratorium Ilmu Tanah dan laboratorium Agronomi Hortikultura, Faperta Unsoed Purwokerto. Bahan yang digunakan yaitu, umbi bawang merah varietas bangkok, tanah ultisol dari Desa Tangeran, Kecamatan Somagede, Kabupaten Banyumas, pupuk hayati mikoriza produksi Laboratorium Agronomi dan Hortikultura Faperta Unsoed, azolla, pupuk Urea, ZA, SP-36, KCl, pupuk kandang, air sumur, paravin, dan aquades.
Alat yang digunakan yaitu sprayer semi otomatik, timbangan dengan ketelitian $50 \mathrm{~g}$, cawan porselin, labu piknometer ukuran $50 \mathrm{ml}$, bobot semprot, timbangan analitik ketelitian 0,1 miligram, pipet ukuran $1 \mathrm{ml}$, beker glass ukuran $250 \mathrm{ml}$ dan $600 \mathrm{ml}$, cassagrande, oven, eksikator, spatula, papan kayu, botol timbang, kamera, cangkul, pancong, ember plastik.

Percobaan menggunakan 2 (dua) faktor, yaitu dosis pupuk hayati Mikola dan dosis pupuk anorganik yang terdiri dari Urea, ZA, SP-36, dan KCl. Aras pupuk Mikola terdiri 3 aras, yaitu:

$$
\begin{aligned}
\mathrm{H} 1= & 10 \mathrm{~g} \text { pupuk mikoriza dan } 0 \mathrm{~g} \text { pupuk } \\
& \text { azolla per polibag setara dengan } 0 \\
& \text { ton pupuk azollaper hektar. } \\
\mathrm{H} 2= & 20 \mathrm{~g} \text { pupuk mikoriza dan } 10 \mathrm{~g} \\
& \text { pupuk azolla per polibag setara } \\
& \text { dengan } 2,5 \text { ton pupuk mikoriza per } \\
& \text { hektar dan } 2,5 \text { ton pupuk azollaper } \\
& \text { hektar } \\
\mathrm{H} 3= & 30 \mathrm{~g} \text { pupuk mikoriza dan } 20 \mathrm{~g} \\
& \text { pupuk azolla per polibag setara } \\
& \text { dengan 5ton pupuk mikoriza per } \\
& \text { hektar dan } 5 \text { ton pupuk azollaper } \\
& \text { hektar. }
\end{aligned}
$$

Aras pupuk anorganik terdiri atas:

$$
\begin{aligned}
\mathrm{P} 0= & \begin{array}{l}
\text { Kontrol } \\
\text { anorganik } \\
\text { anjuran) }
\end{array} \\
\mathrm{P} 1= & \begin{array}{l}
\text { Pengengurangan pupuk } \\
\text { sebesar 25\% dari dosis anjuran }
\end{array} \\
\mathrm{P} 2= & \begin{array}{l}
\text { Pengurangan pupuk dosis } \\
\text { sebesar 50\% dari dosis anjuran }
\end{array} \\
& \text { Penggunaan 100\% dosis pupuk }
\end{aligned}
$$
anorganik terdiri atas $0,8 \mathrm{~g}$ pupuk Urea + 1,6 g Pupuk ZA + 0,4 g pupuk SP-36 +0,8 g pupuk $\mathrm{KCl}$ per pot atau setara dengan 200 
p-ISSN: 1410-0029; e-ISSN2549-6786

Agrin Vol. 23, No. 1, April 2019

$\mathrm{kg}$ pupuk Urea $+400 \mathrm{~kg}$ pupuk $\mathrm{ZA}+100 \mathrm{~kg}$

1. Air tersedia

pupuk SP-36 + $200 \mathrm{~kg}$ pupuk $\mathrm{KCl}$ per

Tabel 3 menunjukkan bahwa hektar.

Rancangan percobaan yang dipilih adalah Rancangan Acak Kelompok (RAK). Percobaan diulang 3 kali sehingga diperoleh 27 unit percobaan. Setiap unit percobaan terdiri dari 25 tanaman bawang merah dengan jumlah tanaman pada petak efektif 9 tanaman. Keragaman data yang diperoleh dianalisis dengan menggunaan uji F pada taraf kepercayaan 95\%. Apabila Uji F berbeda nyata pengujian dilanjutkan dengan uji faktorial regresi. Variabel yang diamati pada penelitian ini meliputi: air tersedia $(\%)$, berat jenis isi $\left(\mathrm{g} / \mathrm{cm}^{3}\right)$, berat jenis partikel $\left(\mathrm{g} / \mathrm{cm}^{3}\right)$, porositas $(\%)$, batas cair $(\%)$, batas berubah warna $(\%)$, tinggi tanaman $(\mathrm{cm})$, bobot umbi segar $(\mathrm{g})$, bobot umbi kering per polibag $(\mathrm{g})$.

\section{HASIL DAN PEMBAHASAN}

Hasil pengamatan rata-rata dan analisis statistiknya disajikan pada Tabel 1. Analisis faktorial lanjutan disajikan pada Tabel 2. Hasil ini memperlihatkan bahwa variabel yang nyata pada uji $\mathrm{F}$ sederhana, dan dilanjutkan dengan uji $\mathrm{F}$ faktorial yang berpengaruh nyata adalah interaksinya, sehingga uji lanjutan diutamakan pada hasil uji interaksi. Hasil penghitungan masingmasing dosis ditunjukkan pada Tabel 3. 
Tabel 1. Hasil pengamatan rata-rata pengaruh perlakuan terhadap variabel yang diamati dan analisis statistiknya

\begin{tabular}{|c|c|c|c|c|c|c|c|c|c|c|c|c|}
\hline No. & Perlakuan & $\begin{array}{c}\text { Air } \\
\text { tersedia } \\
(\%)\end{array}$ & $\begin{array}{c}\text { Berat } \\
\text { Jenis } \\
\text { Isi } \\
\left(\mathrm{g} / \mathrm{cm}^{3}\right) \\
\end{array}$ & $\begin{array}{c}\text { Berat } \\
\text { Jenis } \\
\text { Partikel } \\
\left(\mathrm{g} / \mathrm{cm}^{3}\right) \\
\end{array}$ & $\begin{array}{l}\text { Batas } \\
\text { Cair } \\
(\%)\end{array}$ & $\begin{array}{c}\text { Batas } \\
\text { Berubah } \\
\text { Warna (\%) }\end{array}$ & $\begin{array}{c}\text { Porositas } \\
(\%)\end{array}$ & $\begin{array}{c}\text { Bobot Umbi } \\
\text { segar/ } \\
\text { rumpun }(\mathrm{g})\end{array}$ & $\begin{array}{l}\text { Bobot umbi } \\
\text { kering/rumpun } \\
(\mathrm{g})\end{array}$ & $\begin{array}{l}\text { Tinggi } \\
\text { Tanaman } \\
(\mathrm{cm})\end{array}$ & $\begin{array}{c}\text { Bobot Umbi } \\
\text { Kering/petak } \\
\text { Efektif (g) }\end{array}$ & $\begin{array}{c}\text { Infeksi } \\
\text { mikorisa } \\
(\%)\end{array}$ \\
\hline 1 & H1P0 & 28,47 & 1,34 & 2,42 & 42,70 & 14,23 & 38,76 & 12,03 & 10,99 & 27,59 & 107,28 & 10,67 \\
\hline 2 & $\mathrm{H} 2 \mathrm{P0}$ & 32,16 & 1,37 & 2,38 & 46,16 & 14,00 & 37,46 & 11,31 & 10,00 & 28,09 & 113,17 & 6,67 \\
\hline 3 & H3P0 & 29,56 & 1,32 & 2,42 & 42,16 & 12,60 & 37,00 & 13,66 & 12,23 & 29,71 & 108,90 & 29,00 \\
\hline 4 & H1P1 & 29,46 & 1,37 & 2,22 & 42,62 & 13,16 & 38,26 & 11,93 & 10,96 & 35,33 & 142,67 & 24,33 \\
\hline 5 & $\mathrm{H} 2 \mathrm{P} 1$ & 30,51 & 1,35 & 2,31 & 45,57 & 15,06 & 35,73 & 10,08 & 8,94 & 34,67 & 144,96 & 46,67 \\
\hline 6 & H3P1 & 28,98 & 1,31 & 2,29 & 43,34 & 14,36 & 41,76 & 11,08 & 9,91 & 35,80 & 146,00 & 26,67 \\
\hline 7 & H1P2 & 28,68 & 1,36 & 2,40 & 42,28 & 13,16 & 41,26 & 8,08 & 6,47 & 31,19 & 121,13 & 20,00 \\
\hline 8 & $\mathrm{H} 2 \mathrm{P} 2$ & 30,71 & 1,34 & 2,45 & 44,91 & 14,20 & 36,30 & 8,60 & 6,86 & 31,19 & 119,57 & 17,50 \\
\hline 9 & H3P2 & 28,10 & 1,31 & 2,40 & 41,43 & 13,33 & 39,53 & 7,30 & 5,47 & 33,00 & 122,33 & 33,33 \\
\hline 10 & Uji F & $\mathrm{n}$ & tn & $\mathrm{n}$ & $\mathrm{n}$ & tn & tn & tn & tn & $\mathrm{n}$ & $\mathrm{n}$ & $\mathrm{n}$ \\
\hline
\end{tabular}

Keterangan: $\mathrm{H} 1=10 \mathrm{~g}$ pupuk mikoriza dan $0 \mathrm{~g}$ pupuk azolla per polibag setara dengan 0 ton pupuk azolla per hektar; $\mathrm{H} 2=20 \mathrm{~g}$ pupuk mikoriza dan $10 \mathrm{~g}$ pupuk azolla per polibag setara dengan 2,5 ton pupuk mikoriza per hektar dan 2,5 ton pupuk azolla per hektar; H3=30 g pupuk mikoriza dan $20 \mathrm{~g}$ pupuk azolla per polibag setara dengan 5 ton pupuk mikoriza per hektar dan 5 ton pupuk azolla per hektar; P0 = Kontrol (pengurangan pupuk anorganik sebesar 0\% dari dosis anjuran); P1 = Penggurangan pupuk anorganik sebesar 25\% dari dosis anjuran; P2 = Pengurangan pupuk anorganik sebesar 50\% dari dosis anjuran; $\mathrm{n}=$ nyata pada $\alpha=0,05$ dan $\mathrm{tn}=$ tidak nyata pada $\alpha=$ 0,05 . 
Tabel 2. Hasil analisis faktorial terhadap variabel yang nyata

\begin{tabular}{|c|c|c|c|c|}
\hline \multirow[b]{2}{*}{ No. } & \multirow[b]{2}{*}{ Variabel } & \multicolumn{3}{|c|}{ Efek Perlakuan } \\
\hline & & $\begin{array}{l}\text { Dosis Pupuk } \\
\text { Mikola }\end{array}$ & $\begin{array}{l}\text { Pengurangan dosis } \\
\text { Pupuk N,P dan K }\end{array}$ & Interaksi \\
\hline 1 & Air tersedia & Nyata & Nyata & Nyata \\
\hline 2 & Berat jenis partikel & Nyata & Tidak nyata & Nyata \\
\hline 3 & Batas cair & Tidak nyata & Nyata & Nyata \\
\hline 4 & Tinggi tanaman & Tidak nyata & Nyata & Nyata \\
\hline 5 & Infeksi mikoriza & Nyata & Tidak nyata & Tidak nyata \\
\hline 6 & $\begin{array}{l}\text { Bobot umbi kering/ } \\
\text { petak efektif }(\mathrm{g})\end{array}$ & Nyata & Nyata & Nyata \\
\hline
\end{tabular}

Tabel 3. Hasil Uji Interaksi Pupuk Anorganik dengan pupuk hayati

\begin{tabular}{|c|c|c|c|c|}
\hline No. & Variabel & $\begin{array}{l}\text { Dosis pupuk } \\
\text { anorganik } \\
(\%)\end{array}$ & Persamaan regresi & $\begin{array}{l}\text { Optimasi } \\
\text { pupuk hayati } \\
(\mathrm{g})\end{array}$ \\
\hline \multirow[t]{3}{*}{1} & \multirow[t]{3}{*}{$\begin{array}{l}\text { Air tersedia } \\
(\%)\end{array}$} & $\mathrm{HO}$ & $\begin{array}{l}\mathrm{Ya} 0=28,87+0,2278 \mathrm{x}-0,0058 \mathrm{x}^{2} \\
\mathrm{R}^{2}=76,45 \%\end{array}$ & 39.28 \\
\hline & & $\mathrm{H} 1$ & $\begin{array}{l}Y a 1=28,433+0,47 x-0,012 x^{2} \\
R^{2}=94,18 \%\end{array}$ & 39,17 \\
\hline & & $\mathrm{H} 2$ & $\begin{array}{l}Y a 2=29,1+0,5767 x-0,016 x^{2} \\
R^{2}=97,47\end{array}$ & 36,04 \\
\hline \multirow[t]{3}{*}{2} & \multirow[t]{3}{*}{$\mathrm{BJP}\left(\mathrm{g} / \mathrm{cm}^{3}\right)$} & $\mathrm{HO}$ & $\begin{array}{l}\mathrm{Ya} 0=2,41-0,0158 \mathrm{x}+0,0004 \mathrm{x}^{2} \\
\mathrm{R}^{2}=78,17 \%\end{array}$ & 39,50 \\
\hline & & $\mathrm{H} 1$ & $\begin{array}{l}Y a 1=2.4033-0,012 x+0,0003 x^{2} \\
R^{2}=58,29 \%\end{array}$ & 40,00 \\
\hline & & $\mathrm{H} 2$ & $\begin{array}{l}\mathrm{Ya} 2=2,406-0.0131 \mathrm{x}+0,0003 \mathrm{x}^{2} \\
\mathrm{R}^{2}=63,34 \%\end{array}$ & 43,67 \\
\hline \multirow[t]{3}{*}{3} & \multirow[t]{3}{*}{$\begin{array}{l}\text { Batas } \\
\text { Cair }(\%)\end{array}$} & $\mathrm{HO}$ & $\begin{array}{l}\mathrm{Ya} 0=42,533+0,397 \mathrm{x}+0,0078 \mathrm{x}^{2} \\
\mathrm{R}^{2}=87,74 \%\end{array}$ & 50,90 \\
\hline & & H1 & $\begin{array}{l}\text { Ya } 1=42,81+0,3147 x-0,0076 x^{2} \\
R^{2}=92,7 \%\end{array}$ & 41,41 \\
\hline & & $\mathrm{H} 2$ & $\begin{array}{l}\text { Ya2 }=42,227+0,3219 x-0,0082 x^{2} \\
R^{2}=93,3 \%\end{array}$ & 39,26 \\
\hline \multirow[t]{3}{*}{4} & \multirow{3}{*}{$\begin{array}{l}\text { Tinggi } \\
\text { Tanaman } \\
(\mathrm{cm})\end{array}$} & $\mathrm{HO}$ & $\begin{array}{l}\mathrm{Ya} 0=23,867+1,097 \mathrm{x}-0,0218 \mathrm{x}^{2} \\
\mathrm{R}^{2}=97,6\end{array}$ & 54,51 \\
\hline & & $\mathrm{H} 1$ & $\begin{array}{l}\text { Ya1 }=31,94+0,2707 x-0,0069 x^{2} \\
R^{2}=40,33\end{array}$ & 39.32 \\
\hline & & $\mathrm{H} 2$ & $\begin{array}{l}Y a 2=30,133+0,4233 x-0,0098 \times 2 \\
R^{2}=96,05\end{array}$ & 44,22 \\
\hline 5 & $\begin{array}{l}\text { Infeksi } \\
\text { Mikoriza (\%) }\end{array}$ & $\mathrm{H}$ & $\begin{array}{l}Y=17,33+1,9001 x-0,0419 x^{2} \\
R^{2}=83,96\end{array}$ & 45,35 \\
\hline \multirow[t]{3}{*}{6} & \multirow{3}{*}{$\begin{array}{l}\text { Bobot Umbi } \\
\text { kering/petak } \\
\text { efektif }(\mathrm{g})\end{array}$} & $\mathrm{HO}$ & $\begin{array}{l}Y a 0=109,52+3,270 x-0,0806 x^{2} \\
R^{2}=91,98\end{array}$ & 40,62 \\
\hline & & H1 & $\begin{array}{l}Y a 1=112+2,4833 x-0.0608 x^{2} \\
R^{2}=96,23\end{array}$ & 40,84 \\
\hline & & $\mathrm{H} 2$ & $\begin{array}{l}Y a 2=119,33+1,8 x-0,0457 x^{2} \\
R^{2}=95,42\end{array}$ & 39,39 \\
\hline
\end{tabular}




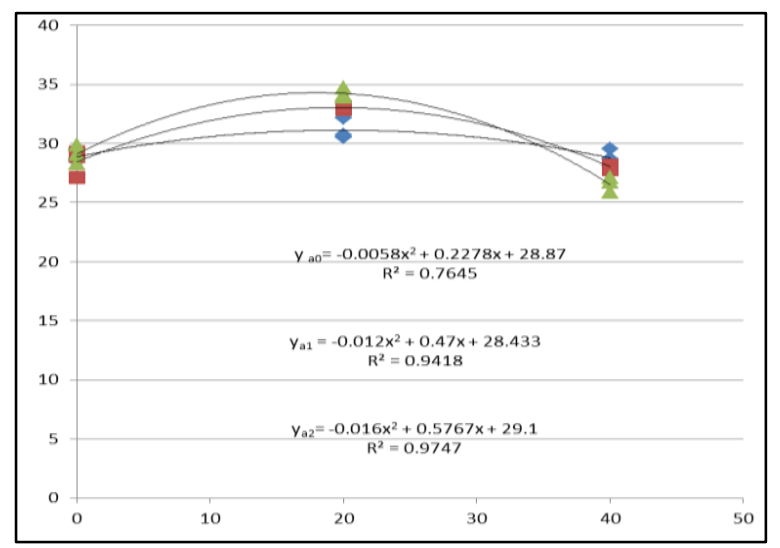

Gambar 1. Hubungan pemberian pupuk hayati dengan air tersedia pada masing-masing pupuk anorganik.

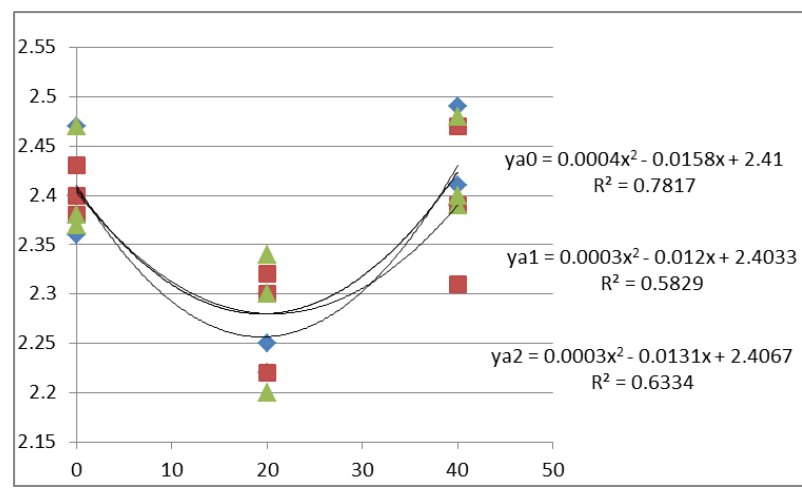

Gambar 2. Hubungan pemberian pupuk hayati dengan berat jenis partikel pada masing-masing pupuk anorganik.

2. Berat jenis partikel

Tabel 3 menunjukkan bahwa pemberian pupuk hayati pada masingmasing dosis pupuk anorganik terhadap Berat Jenis Partikel (BJP) memberikan respon kuadratik dengan persamaan untuk A0 yaitu, $\mathrm{Ya} 0=2,41-0,015 \mathrm{x}+0,0004 \mathrm{x}^{2}$ dengan $\mathrm{R}^{2}=78,17 \%$, untuk $\mathrm{A} 1$ yaitu, $\mathrm{Ya} 1=$ $2.4033-0,012 \mathrm{x}+0,0003 \mathrm{x}^{2}$ dengan $\mathrm{R}^{2}=$ $58,29 \%$ dan untuk A2 yaitu, Ya2 $=2,4067$ $0.0131 x+0,0003 x^{2}$ dengan $R^{2}=63,34 \%$. Hal ini diduga bahwa pada awalnya pemberian pupuk hayati bersama-sama dengan pupuk anorganik dapat meningkatkan berat jenis partikel, tetapi setelah mencapai titik maksimal peningkatan pupuk hayati justru akan menurunkan nilai BJI. Titik optimasi masing masing titik adalah: $39,50 \%$ untuk A0; $40 \%$ untuk A1; dan $43,67 \%$ untuk A2. Hal ini menunjukkan bahwa pada pengurangan $50 \%$ dosis anjuran, berat jenis partikel menjadi rendah karena berkembangnya hifa mikoriza dan perbaikan agregat tanah dengan adanya Azolla. Garis regresi hubungan antara dosis pupuk hayati dengan berat jenis partikel tanaman pada masing-masing dosis pupuk anorganik disajikan pada Gambar 2. 


\section{Batas Cair}

Tabel 3 menunjukkan bahwa pemberian pupuk hayati pada masingmasing dosis pupuk anorganik terhadap Berat Jenis Partikel (BJP) memberikan respon kuadratik dengan persamaan untuk A0 yaitu, $\mathrm{Ya} 0=42,533+0,3969 \mathrm{x}+$ $0,0078 x^{2}$ dengan $R^{2}=87,74 \%$, untuk $A 1$ yaitu, Ya1 $=42,81+0,3147 x-0,0076 x^{2}$ dengan $\mathrm{R}^{2}=92,7 \%$ dan untuk $\mathrm{A} 2$ yaitu, Ya2 $=42,227+0,3219 x-0,0082 x^{2}$ dengan $R^{2}=$ 93,3\%. Hal ini memberi indikasi bahwa pada awal pemberian pupuk hayati bersama-sama dengan pupuk anorganik dapat meningkatkan BJP, tetapi setelah mencapai titik maksimal meningkatnya pupuk hayati justru akan menurunkan nilai BJP. Titik optimasi setiap titik adalah $50,90 \%$ untuk A0; 41,41\% untuk A1; dan $39,26 \%$ untuk A2. Garis regresi hubungan antara dosis pupuk hayati dengan batas cair pada masing-masing dosis pupuk anorganik disajikan pada Gambar 3.

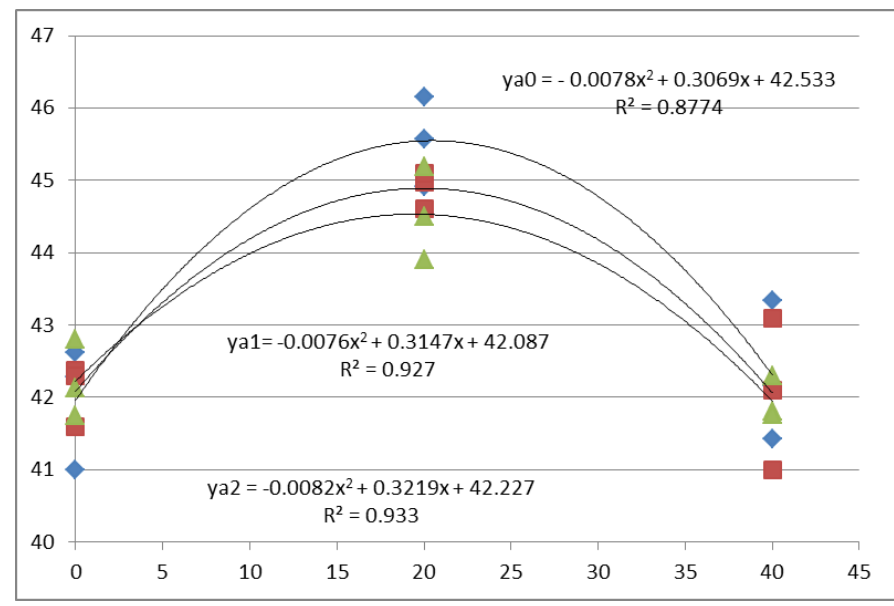

Gambar 3. Hubungan pemberian pupuk hayati dengan batas cair pada masing-masing pupuk anorganik.

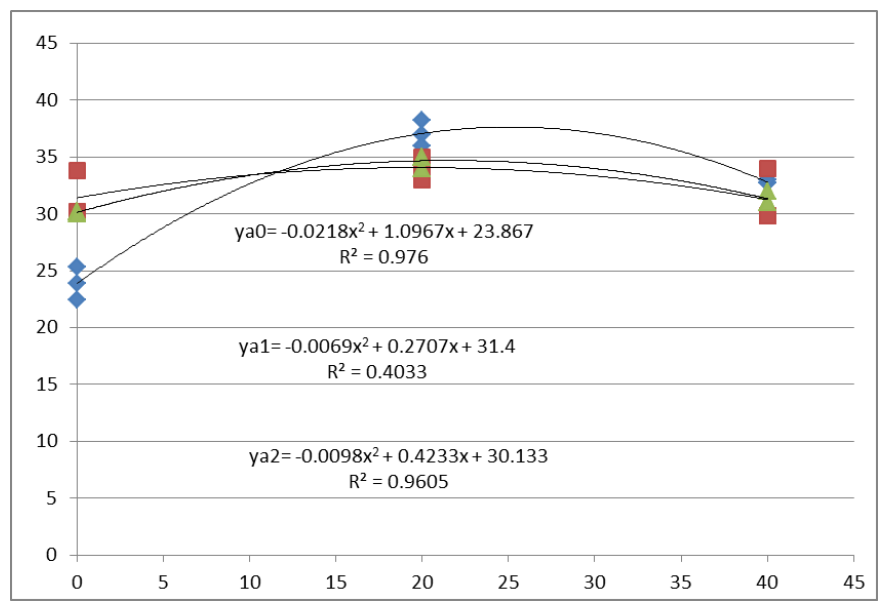

Gambar 4. Hubungan pemberian pupuk hayati dengan tinggi tanaman pada masing-masing pupuk anorganik. 
4. Tinggi Tanaman

Tabel 3 menunjukkan bahwa pemberian pupuk hayati pada masingmasing dosis pupuk anorganik terhadap tinggi tanaman memberikan respon kuadratik dengan persamaan untuk A0 yaitu, $\mathrm{Ya} 0=42,533+0,3969 \mathrm{x}+0,0078 \mathrm{x}^{2}$ dengan $\mathrm{R}^{2}=87,74 \%$, untuk $\mathrm{A} 1$ yaitu, $\mathrm{Ya} 1=$ $42,81+0,3147 \mathrm{x}-0,0076 \mathrm{x}^{2}$ dengan $\mathrm{R}^{2}=$ 92,7\% dan untuk A2 yaitu, Ya2 = $42,227+0,3219 x-0,0082 x^{2}$ dengan $R^{2}=$ 93,3\%. Hal ini memberi indikasi bahwa pada awalnya pemberian pupuk hayati bersama-sama dengan pupuk anorganik dapat meningkatkan tinggi tanaman, tetapi setelah mencapai titik maksimal peningkatan pupuk hayati Mikola justru menurunkan tinggi tanaman. Titik optimasi masing-masing titik adalah: 54,51 g/tanaman untuk A0; 39,32 g/tanaman untuk A1; dan 44,22 g/tanaman untuk A2. Garis regresi hubungan antara dosis pupuk hayati dengan tinggi tanaman pada setiap dosis pupuk anorganik disajikan pada Gambar 4.

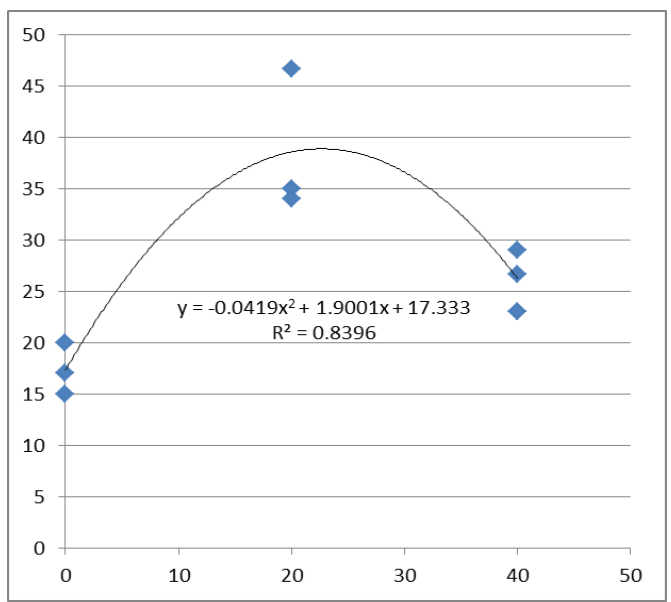

Gambar 5. Hubungan pemberian pupuk hayati dengan infeksi mikoriza pada masing-masing pupuk anorganik.

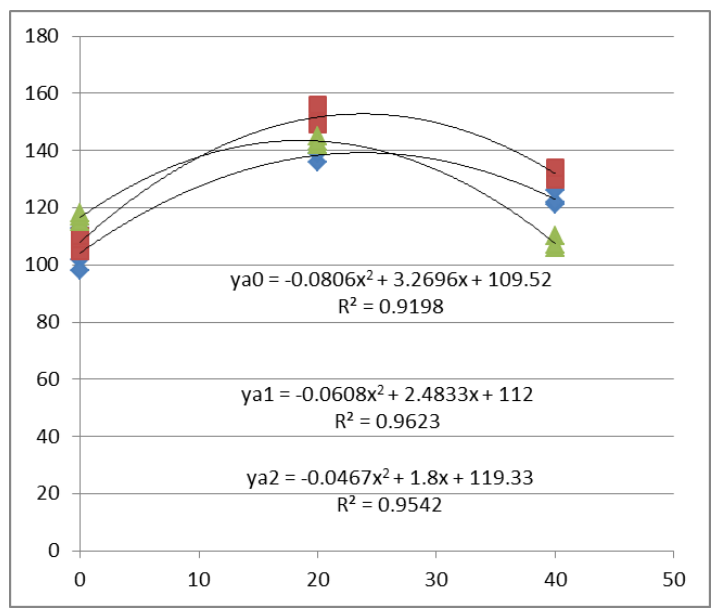

Gambar 6. Hubungan pemberian pupuk hayati dengan bobot umbi kering petak efektif pada masing-masing pupuk anorganik. 
p-ISSN: 1410-0029; e-ISSN2549-6786

Agrin Vol. 23, No. 1, April 2019

5. Infeksi Mikoriza

Tabel 3 menunjukkan bahwa pemberian pupuk hayati berpengaruh nyata secara mandiri dalam respon kuadratik terhadap infeksi mikoriza. Hal ini menggambarkan bahwa pada awalnya semakin meningkatnya pemberian mikola secara mandiri besarnya infeksi mikoriza akan meningkat, tetapi setelah mencapai titik optimun dengan meningkatnya pemberian Mikola akan menurunkan infeksi mikoriza. Hal ini dapat dipahami karena semakin tinggi pupuk hayati mikola yang diberikan membuat terjadinya persaingan pertumbuhan mikoriza. Persamaan respon hubungan pemberian pupuk mikola dengan infeksi mikoriza adalah: $\mathrm{Y}=17,333+1,90 \mathrm{x}-0,0419 \mathrm{x}^{2}$ dengan R2 $=83.96 \%$. Pada hubungan regresi ini memberikan titik optimasi pupuk Mikola sebesar 45,35 g/tanaman.

6. Bobot umbi kering petak efektif

Tabel 3 menunjukkan bahwa pemberian pupuk hayati pada masingmasing dosis pupuk anorganik terhadapbobot umbi kering petak efektif memberikan respon kuadratik dengan persamaan untuk A0 yaitu, Ya0 $=109,52+$ $3.269 \mathrm{x}-0,0806 \mathrm{x}^{2}$ dengan $\mathrm{R}^{2}=91,98 \%$, untuk A1 yaitu, Ya1= $112+2,4833 x-$ $0,0608 x^{2}$ dengan $R^{2}=96,23 \%$ dan untuk $A 2$ yaitu, $\mathrm{Ya} 2=119,33+1,8 \mathrm{x}-0,0467 \mathrm{x}^{2}$ dengan $\mathrm{R}^{2}=95,42 \%$. Hal ini memberi indikasi bahwa pada awalnya pemberian pupuk hayati bersama-sama dengan pupuk anorganik dapat meningkatkan bobot umbi kering petak efektif, tetapi setelah mencapai titik maksimal meningkatnya pupuk hayati Mikola akan menurunkan bobot umbi kering petak efektif. Titik optimasi masing masing titik adalah: 40,62 $\mathrm{g} /$ tanaman untuk A0;40,84 g/tanaman untuk A1; dan 39,39 g/tanaman untuk A2. Garis regresi hubungan antara dosis pupuk hayati dengan bobot umbi kering petak efektif pada masing-masing dosis pupuk anorganik disajikan pada Gambar 6.

\section{KESIMPULAN}

Aplikasi pupuk hayati mikoriza dan azolla pada dosis 39-50 g mampu mengurangi penggunaan pupuk $\mathrm{N}, \mathrm{P}, \mathrm{K}$ sintetik sekitar $40 \%$ dari dosis anjuran.

\section{DAFTAR PUSTAKA}

Adiyogo, W. 1999. Pola pertumbuhan produksi beberapa jenis sayuran di Indonesia. Jurnal Hortikultura, 9(3): $258-265$.

Ansyar, I.A., F. Silvina, dan Murniati. 2017. Pengaruh pupuk kascing dan mikoriza terhadap pertumbuhan dan produksi tanaman bawang merah. JOM Faperta, 4(1): 1 - 13.

Badan Litbang Pertanian. 2007. Prospek dan Arah Pengembangan Agribisnis: Bawang Merah. Badan Penelitian dan Pengembangan Pertanian, Kemeterian Pertanian, Jakarta.

Fuady, Z. 2013. Kontribusi cendawan mikoriza arbuskular terhadap pembentukan agregat tanah dan 
pertumbuhan tanaman. Jurnal Lentera, 13(3): 7- 15.

Habte, M. and A. Manjunath. 1991. Categories of vesicular-arbuscular mycorrhizal dependency of host species. Mycorrhiza, 1(1): 3-12.

Hardjowigeno, S.2007. Ilmu Tanah. Akademika Pressindo, Jakarta.

Masria. 2008. Peranan Mikoriza Vesikular Arbuskular (MVA) untuk meningkatkan resistensi tanaman terhadap cekaman kekeringan dan ketersedian $\mathrm{P}$ pada lahan kering. Partner, 15(1): 48 - 56.

Rokhminarsi, E. Hartati, Suwandi. 2007. Pertumbuhan dan hasil tomat ceri pada pemberian pupuk hayati mikoriza, azolla, serta pengurangan pupuk N dan P. Agrin, 11(2): 92 102.

Syarief, S. 1985.Ilmu Tanah Pertanian. Pustaka Buana Bandung, Bandung.

Sasli, I. 2004. Peranan Mikoriza Vesikula Arbuskula (MVA) dalam peningkatan resistensi tanaman terhadap cekaman kekeringan.

Makalah pribadi. Sekolah Pascasarjana, IPB, Bogor.

Setiadi, Y. 1998. Fungi Mikoriza Arbuskula dan Prospeknya sebagai Pupuk Biologis. Prosiding Workshop Aplikasi Cendawan Mikoriza Arbaskular pada Tanaman Pertanian, Perkebunan dan Kehutanan. PAU Bioteknologi IPB, Bogor.

Simarwata, T., Y. Sumarni, D.H. Arief. 2001. Optimalisasi rancang bangun terknologi pada pertanian organik (organic farming) dan pertanian ekologis terpadu (integrated ecological farming systems). Makalah disampaikan pada Seminar Penggunaan Cendawan Mikoriza dalam Sistem Pertanian Organik dan Rehabilitasi Lahan Kritis. Bandung, 23 April 2001.

Yuwono, N.W. 2009. Membangun kesuburan tanah di lahan marginal. Jurnal Ilmu Tanah dan Lingkungan, 9(2): $137-141$. 